\title{
Genetic Diversity within the Population of Xanthomonas oryzae pv. oryzae in India
}

\author{
J. Yashitola, D. Krishnaveni, A. P. K. Reddy, and R. V. Sonti
}

First and fourth authors: Centre for Cellular and Molecular Biology, Uppal Road, Hyderabad-500007, A. P., India; and second and third authors: Directorate of Rice Research, Indian Council of Agricultural Research, Rajendranagar, Hyderabad-500030, A. P., India. Accepted for publication 3 April 1997.

\begin{abstract}
Yashitola, J., Krishnaveni, D., Reddy, A. P. K., and Sonti, R. V. 1997. Genetic diversity within the population of Xanthomonas oryzae pv. oryzae in India. Phytopathology 87:760-765.

Xanthomonas oryzae pathovar oryzae causes a serious disease of rice in India and is endemic in all of the major rice-growing areas of the country. Sixty-seven $X$. oryzae pv. oryzae strains, collected mostly in 1994 and 1995, from 18 locations in India were analyzed by DNA fingerprinting methods using two separate repeat element probes from the $X$.

oryzae pv. oryzae genome. These results show that strains belonging to a single pathogen lineage can be isolated from 16 of the 18 locations sampled; many of these locations are separated from each other by hundreds of kilometers and represent ecologically diverse rice-growing areas. Pathotyping analysis indicated that the strains in this lineage belong to pathotype $1 \mathrm{~b}$ of $X$. oryzae pv. oryzae.

Additional keywords: bacterial blight of rice, pathogen populations, rice pathogen.
\end{abstract}

Xanthomonas oryzae pathovar oryzae (25) causes bacterial leaf blight, a serious disease of rice. Since the first reports of the pathogen in India $(2,23)$, it has been found in all of the major ricegrowing areas (24). Variation in the spectrum of virulence among different strains has been reported $(3,5,11,20)$. Pathotype studies conducted under the All India Coordinated Rice Improvement Project during the last 20 years indicate that pathotypes $1 \mathrm{a}$ and $1 \mathrm{~b}$ are widely distributed in India $(18,19)$. These two pathotypes exhibit a similar virulence spectrum and are unable to cause disease on rice cultivars $\mathrm{BJ} 1$ and DV85. They are distinguished from each other on the basis of their reaction pattern on the IR20 rice cultivar, which carries the $\mathrm{Xa}-4$ disease-resistance gene. Pathotype 1a strains are incompatible on IR20, whereas pathotype 1b strains are compatible. However, race studies based on differential cultivars may not indicate the true level of genetic diversity within a pathogen population. Molecular techniques such as restriction fragment length polymorphism (RFLP) have provided new tools to more accurately assess the genetic diversity of pathogen populations and have been used extensively for this purpose.

RFLP analyses have been successfully used to detect genetic variability within populations of $X$. oryzae pv. oryzae in the Philippines $(14,16)$ and in a broad survey of strains from different countries in Asia (1). We have initiated RFLP studies, with probes that were used in these earlier studies, to assess the population structure of this pathogen in India. The results reported here indicate that a single lineage consisting of closely related $X$. oryzae pv. oryzae strains is present in widely separated locations within India. The reactions of these strains on rice differential cultivars are similar to those of pathotype $1 \mathrm{~b}$.

\section{MATERIALS AND METHODS}

Strain collection. Strains of $X$. oryzae pv. oryzae were isolated from naturally infected rice plants collected from 18 widely dis-

Corresponding author: R. V. Sonti; E-mail address: sonti@ccmb.globemail.com

Publication no. P-1997-0429-01R

(c) 1997 The American Phytopathological Society persed geographical locations within India (Fig. 1). Information on bacterial strains, geographical locations, host cultivars, and year of collection are listed in Table 1. The strains were collected by A. P. K. Reddy in collaboration with other scientists in the All India Coordinated Rice Improvement Project. The locations that are listed in Table 1 are the base sites from which farmers' fields in the neighboring villages were surveyed. A few infected leaf samples were collected at random from these fields. The names of these villages and their geographical locations are available upon request. From each village, isolations were made and one strain/ village was maintained as a representative strain. When multiple strains were referred from one location, each strain was obtained from a different village in the surveyed area. Bacterial strains collected from the Taichung Native-1 (TN-1) rice cultivar were not obtained from farmers' fields, but from the campuses of agricultural research stations. BXO4, BXO5, and BXO6 were collected from farmers' fields and provided by C. L. Raina, Agricultural Research Station, Kapurthala. BXO2 and BXO3 were provided by V. S. Trimurty, Indira Gandhi Agricultural University, Raipur.

Growth of bacteria. All the strains of $X$. oryzae pv. oryzae were isolated and routinely grown on peptone sucrose agar $(8,26)$ at $28^{\circ} \mathrm{C}$. For long-term storage, strains were grown in peptone sucrose and frozen at $-70^{\circ} \mathrm{C}$ in $20 \%$ glycerol. All the strains collected were test-inoculated onto the susceptible $\mathrm{TN}-1$ rice cultivar to confirm their pathogenicity.

Hybridization probes. Two different repeat elements from the $X$. oryzae pv. oryzae genome were used as hybridization probesthe avirulence gene probe called $a v r X a 10$ (9) and the insertion element probe IS1112 (14). These probes have been previously used to detect genetic variability within the population of this pathogen in the Philippines and other locations in Asia $(1,13,16)$.

DNA isolation and Southern hybridization. Bacteria were grown for $18 \mathrm{~h}$ in peptone sucrose medium on a rotary shaker at $28^{\circ} \mathrm{C}$, and genomic DNA was isolated according to the protocol of Leach et al. (14) and stored at $4^{\circ} \mathrm{C}$. Genomic DNA was digested with restriction endonucleases BamHI or EcoRI (New England Biolabs Inc., Beverly, MA) for $3 \mathrm{~h}$ at $37^{\circ} \mathrm{C}$. Three micrograms of completely digested DNA from each strain were separated electrophoretically on $0.7 \%$ agarose gels, denatured, neutralized, and 
vacuum-transferred to Hybond N (Amersham Life Science, Buckinghamshire, England) membranes according to the procedure given by Sambrook et al. (21). DNA was cross-linked to membranes using an UV Stratalinker (Stratagene Inc., La Jolla, CA). Blots were prehybridized in a solution of $0.5 \mathrm{M}$ sodium phosphate ( $\mathrm{pH} 7.2$ ), $7 \%$ sodium dodecyl sulfate (SDS), $1 \%$ bovine serum albumin, and $1 \mathrm{mM}$ EDTA for $3 \mathrm{~h}$ at $65^{\circ} \mathrm{C}$. Probes were labeled with $\alpha^{32} \mathrm{P}$-dATP and hybridized for $18 \mathrm{~h}$ at $65^{\circ} \mathrm{C}$ with constant shaking. Blots were washed at $65^{\circ} \mathrm{C}$ with $2 \times \mathrm{SSC}(1 \times \mathrm{SSC}$ is $0.15 \mathrm{M} \mathrm{NaCl}$ plus $0.015 \mathrm{M}$ sodium citrate, $\mathrm{pH} 7.0$ ), $0.1 \%$ SDS, and $5 \mathrm{mM}$ sodium phosphate (pH 7.0) three times for $20 \mathrm{~min}$ each and with $0.5 \times \mathrm{SSC}, 0.1 \% \mathrm{SDS}$, and $3 \mathrm{mM}$ sodium phosphate buffer ( $\mathrm{pH}$ 7.0) three times for 20 min each. Autoradiography was done with X-ray film at $-70^{\circ} \mathrm{C}$. A kilobase DNA ladder (Stratagene Inc.) was added to all the gels as a marker. After transfer, the membrane was cut, and the lane carrying the marker was hybridized separately.

RFLP analysis. The haplotype (banding pattern) of each strain obtained by Southern hybridization was compared with all the other strains, and presence or absence of a particular band was recorded as 1 and 0 , respectively (4). The data was analyzed by the similarity coefficient of Nei and Li (15): $(2 N x y) /(N x+N y) . N x y$ is the number of bands common to strains $x$ and $y ; N x$ and $N y$ are the number of bands in strains $x$ and $y$, respectively. Dendrograms were prepared by the UPGMA (unweighted pair group method of averages) option of the NEIGHBOR program of PHYLIP (Phylogeny inference package) (7). For each set of data, the program was run 10 to 15 times by randomizing the sequence of input data and using different seed numbers as prescribed (7). Identical clusters of strains were obtained in different runs. The confidence limits of dendrograms were determined by bootstrap analysis with 2,000 replications using the WinBoot program (27). The bootstrap values are expressed as a percentage of these 2,000 replications. The higher the bootstrap value for a particular group, the greater is the confidence that this group is real and not pro-

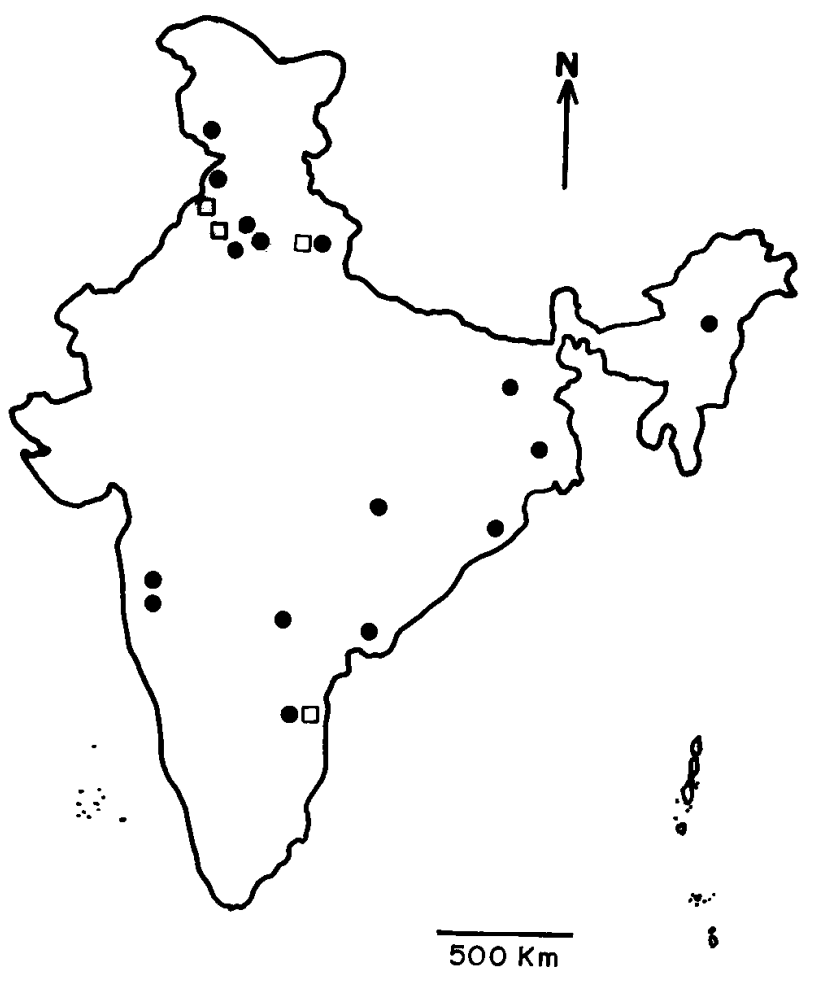

Fig. 1. Collection sites of Xanthomonas oryzae pv. oryzae strains from India. Details of the collection sites are provided in Table 1. Filled circles indicate collection sites of strains belonging to a widely distributed lineage (described in Results). Open squares indicate strains that are not part of this lineage.
TABLE 1. Xanthomonas oryzae pv. oryzae strains collected from rice cultivars grown at different locations in India

\begin{tabular}{|c|c|c|c|}
\hline Strain & Location & $\begin{array}{l}\text { Rice } \\
\text { cultivar }\end{array}$ & Year \\
\hline BXO1 & Chinsuria, West Bengal & $\mathrm{NA}^{\mathrm{a}}$ & 1992 \\
\hline $\mathrm{BXO} 2$ & Raipur, Madhya Pradesh & NA & 1991 \\
\hline BXO3 & Raipur, Madhya Pradesh & NA & 1991 \\
\hline BXO4 & Kapurthala, Punjab & PR106 & 1992 \\
\hline BXO5 & Ferozpur, Punjab & PR106 & 1992 \\
\hline BXO6 & Patiala, Punjab & PR106 & 1992 \\
\hline BXO7 & Titabar, Assam & NA & 1992 \\
\hline BXO8 & Nellore, Andhra Pradesh & NLR9672 & 1993 \\
\hline BXO9 & Jammu \& Kashmir & Jaya & 1993 \\
\hline BXO10 & Cuttack, Orissa & NA & 1993 \\
\hline BXO11 & Cuttack, Orissa & NA & 1993 \\
\hline BXO12 & Maruteru, Andhra Pradesh & Krishnaveni & 1994 \\
\hline BXO13 & Maruteru, Andhra Pradesh & Krishnaveni & 1994 \\
\hline BXO14 & Maruteru, Andhra Pradesh & Krishnaveni & 1994 \\
\hline BXO15 & Maruteru, Andhra Pradesh & Krishnaveni & 1994 \\
\hline BXO16 & Maruteru, Andhra Pradesh & Krishnaveni & 1994 \\
\hline BXO17 & Pantnagar, Uttar Pradesh & NA & 1994 \\
\hline BXO18 & Pantnagar, Uttar Pradesh & NA & 1994 \\
\hline BXO19 & Pantnagar, Uttar Pradesh & NA & 1994 \\
\hline BXO20 & Pantnagar, Uttar Pradesh & NA & 1994 \\
\hline BXO25 & Raigad, Maharashtra & Jaya & 1994 \\
\hline BXO26 & Raigad, Maharashtra & Jaya & 1994 \\
\hline BXO27 & Raigad, Maharashtra & Jaya & 1994 \\
\hline BXO28 & Kapurthala, Punjab & PR106 & 1994 \\
\hline BXO29 & Kapurthala, Punjab & PR106 & 1994 \\
\hline BXO30 & Kapurthala, Punjab & PR106 & 1994 \\
\hline BXO31 & Kapurthala, Punjab & PR106 & 1994 \\
\hline BXO32 & Kapurthala, Punjab & PR106 & 1994 \\
\hline BXO33 & Kurukshetra, Haryana & PR106 & 1994 \\
\hline BXO34 & Karnal, Haryana & Basmati & 1994 \\
\hline BXO35 & Karnal, Haryana & Basmati & 1994 \\
\hline BXO36 & Karnal, Haryana & Basmati & 1994 \\
\hline BXO37 & Karnal, Haryana & Basmati & 1994 \\
\hline BXO38 & Hyderabad, Andhra Pradesh & $\mathrm{TN}-1^{\mathrm{b}}$ & 1994 \\
\hline BXO40 & Pusa, Bihar & $\mathrm{TN}-1$ & 1994 \\
\hline BXO401 & Maruteru, Andhra Pradesh & Chaitanya & 1995 \\
\hline BXO403 & Maruteru, Andhra Pradesh & Krishnaveni & 1995 \\
\hline BXO405 & Maruteru, Andhra Pradesh & Krishnaveni & 1995 \\
\hline BXO407 & Karjat, Maharashtra & KJT184 & 1995 \\
\hline ВXO409 & Karjat, Maharashtra & Jaya & 1995 \\
\hline BXO411 & Karjat, Maharashtra & Jaya & 1995 \\
\hline BXO413 & Kaul, Haryana & Basmati & 1995 \\
\hline BXO414 & Kaul, Haryana & Basmati & 1995 \\
\hline BXO415 & Kaul, Haryana & Basmati & 1995 \\
\hline BXO416 & Kaul, Haryana & PR106 & 1995 \\
\hline BXO417 & Kaul, Haryana & PR106 & 1995 \\
\hline BXO418 & Kaul, Haryana & PR106 & 1995 \\
\hline BXO419 & Nellore, Andhra Pradesh & NA & 1995 \\
\hline BXO421 & Nellore, Andhra Pradesh & NA & 1995 \\
\hline $\mathrm{BXO} 423$ & Nellore, Andhra Pradesh & NA & 1995 \\
\hline BXO432 & Raigad, Maharashtra & Ratna & 1995 \\
\hline BXO433 & Raigad, Maharashtra & Ratna & 1995 \\
\hline BXO434 & Raigad, Maharashtra & Ratna & 1995 \\
\hline BXO435 & Raigad, Maharashtra & Ratna & 1995 \\
\hline BXO436 & Raigad, Maharashtra & Ratna & 1995 \\
\hline BXO437 & Raigad, Maharashtra & Ratna & 1995 \\
\hline BXO438 & Raigad, Maharashtra & Ratna & 1995 \\
\hline BXO439 & Kaul, Haryana & PR106 & 1995 \\
\hline BXO440 & Kaul, Haryana & Jaya & 1995 \\
\hline BXO441 & Kaul, Haryana & Jaya & 1995 \\
\hline BXO442 & Kaul, Haryana & Jaya & 1995 \\
\hline BXO443 & Pantnagar, Uttar Pradesh & NA & 1995 \\
\hline BXO444 & Pantnagar, Uttar Pradesh & NA & 1995 \\
\hline BXO445 & Pantnagar, Uttar Pradesh & NA & 1995 \\
\hline BXO446 & Pantnagar, Uttar Pradesh & NA & 1995 \\
\hline BXO447 & Pantnagar, Uttar Pradesh & NA & 1995 \\
\hline ВXO448 & Kaul, Haryana & Jaya & 1995 \\
\hline
\end{tabular}

a NA indicates that information is not available.

b $\mathrm{TN}-1=$ Taichung Native- 1 rice cultivar. 
duced as an artifact of the clustering process (27). Felsenstein (6) proposed a very stringent criterion and suggested that only groups having a bootstrap value $>95 \%$ should be considered to be robust.

Pathotype analysis. The seeds of the rice differential cultivars were obtained from the Directorate of Rice Research. The plants were grown in plastic pots $(17-\mathrm{cm}$ diameter $\times 15$-cm height) under flooded conditions in the greenhouse on soil obtained from the rice farm of the Directorate of Rice Research. The pots were filled with a mixture of soil and farmyard manure at a ratio of 3:1. N-P-K were supplied to the plants at the rate of $100-75-75 \mathrm{~kg} / \mathrm{ha}$ as the
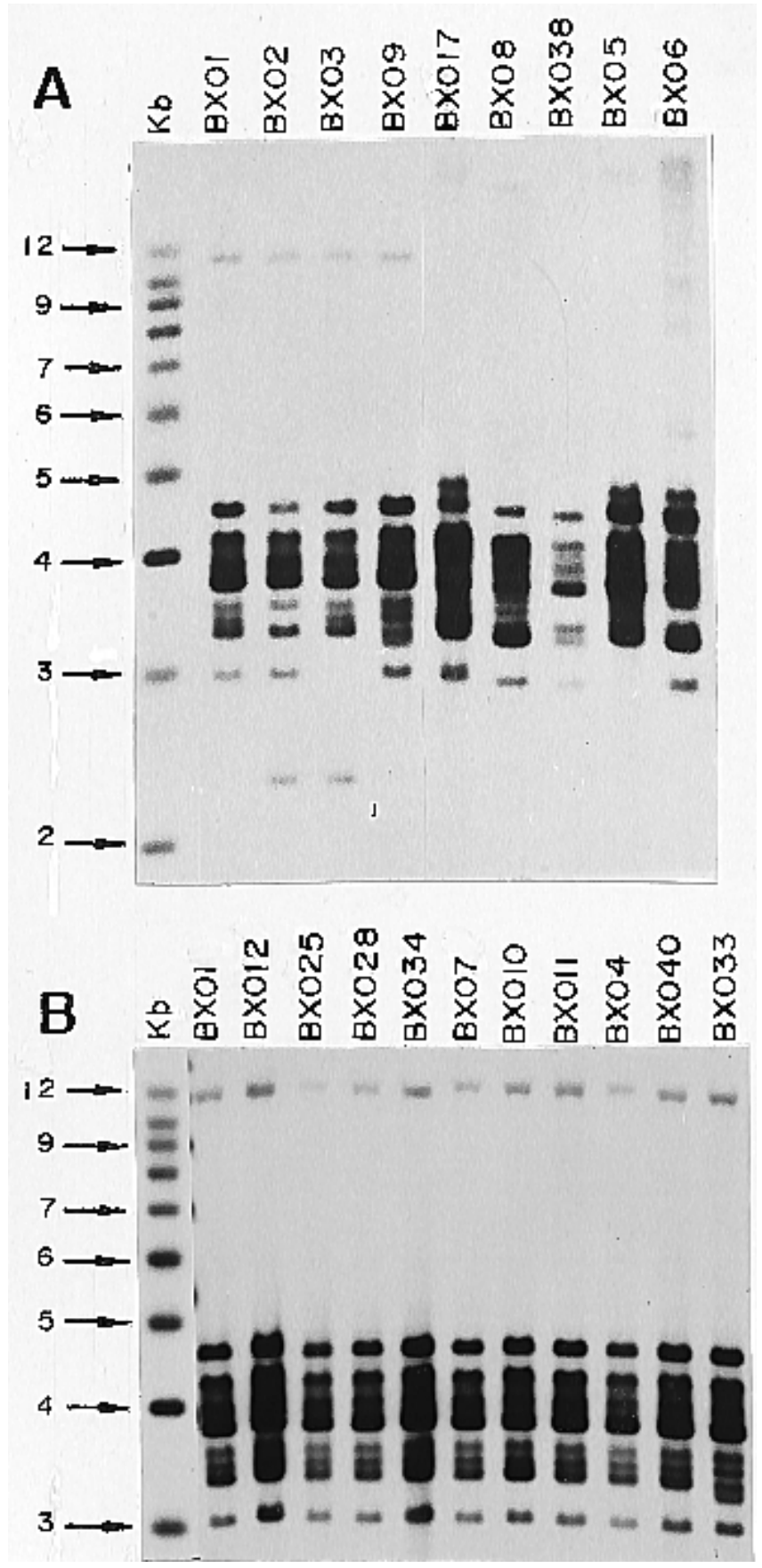

Fig. 2. Haplotype diversity within Indian strains of Xanthomonas oryzae pv. oryzae revealed by the probe avrXa10. Genomic DNA was isolated from bacterial strains collected from different locations in India. BamHI-digested genomic DNA was probed with radio-labeled $a v r X a 10$. The strain number is indicated on each lane. A kilobase DNA ladder was added as a size marker. Each strain was analyzed at least three times, and the same haplotype was obtained every time. A, Haplotype diversity. B, Haplotypes of a group of closely related strains. basal dose in the form of urea, superphosphate, and muriate of potash. Fifteen-day-old rice seedlings were transplanted to these pots. Five seedlings were planted in each pot, taking care to give equal spacing between the seedlings. The pots were irrigated every day. The plants were top-dressed with urea at the rate of $50 \mathrm{~kg} / \mathrm{ha}$ at the tillering stage. Adequate plant protection measures were taken to ensure healthy and vigorous growth of the plants. Forty-dayold plants were clip-inoculated (12) with bacterial suspensions of $10^{9} \mathrm{cells} / \mathrm{ml}$. An average of 20 leaves per pot were inoculated for each strain-cultivar combination.

Disease scores were evaluated 15 days after inoculation based on a 0 to 9 scale $(10,12)$ : $0=$ no visible lesion; $1=$ lesions restricted to 0.5 to $1.0 \mathrm{~mm} ; 3=$ lesions elongated, but less than one-fourth of the leaf blade; $5=$ lesions extended to half of the leaf blade; $7=$ lesions extended from three-fourths to the base of the leaf blade; and $9=$ lesions completely destroyed the leaf blade and sheath. A disease score of 4 and below was rated as a resistant reaction, 4 to 5 as a moderately susceptible reaction, and 5 and above as a susceptible reaction $(10,12)$.

\section{RESULTS}

RFLP analysis with the avrXa10 probe. Sixty-seven strains of $X$. oryzae pv. oryzae were analyzed for RFLPs using the avirulence gene probe avrXa10. There were nine distinct haplotypes (Fig. 2A), based on the 19 distinct bands observed. DNA fragments that hybridized ranged from 12 to $2 \mathrm{~kb}$. The number of bands in each haplotype varied from a minimum of seven bands in BXO38 to as many as 11 bands in BXO8 and BXO17. The most common haplotype among the strains analyzed was the BXO1 type of banding pattern. Figure 2B shows the BXO1 haplotype exhibited by strains collected from different geographical locations in India. Among the 67 strains analyzed, 55 strains from 12 different locations had this haplotype.

Similarity coefficients for pairwise combinations of haplotypes were obtained, and a dendrogram was prepared (Fig. 3A) with the UPGMA option of PHYLIP. A single dominant lineage (clustering at the $88 \%$ similarity level) was formed by 59 strains from 15 locations; this lineage included the haplotype represented by BXO1. The strains BXO5 and BXO17 formed a second group (85\% similarity level). BXO6 and BXO8 did not cluster strongly with any of the other lineages; BXO38 clustered with the dominant lineage at the $80 \%$ similarity level. Low bootstrap values were obtained for all of these clusters. These values improved to $97.7 \%$ for the dominant lineage and $95.2 \%$ for the group of BXO5 and BXO17 when

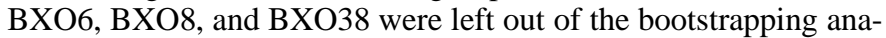
lysis. Cluster analysis of the data using the NEIGHBOR JOINING option of the PHYLIP program gave the same clusters as with UPGMA (J. Yashitola, unpublished data).

Haplotype variability of multiple strains from a single location. It was observed that, in many cases, multiple strains from the same locality (Table 1) had an identical haplotype. All of the strains from Maruteru (BXOs 12, 13, 14, 15, 16, 401, 403, and 405) had an identical haplotype, and only the haplotype of BXO12 is shown (Fig. 2B). Similarly, all of the strains collected from Pantnagar in 1994 (BXOs 17, 18, 19, and 20) had a haplotype identical to that of BXO17 (Fig. 2A). Identical haplotypes were observed for multiple strains collected from each of several other locations including Cuttack, Kapurthala, Karjat, Karnal, Maruteru, and Raigad. The Kapurthala strains (BXOs 4, 28, 29, 30, 31, and 32) had the same haplotype, even though $\mathrm{BXO} 4$ was collected in 1992, while the rest were collected in 1994. In contrast, the Nellore strain BXO8, which was collected in 1993, had a haplotype distinct from BXO419, BXO421, and BXO423, which were collected in 1995 from the same location. All of the 1995 strains exhibited one haplotype. Similarly, Pantnagar strains BXO17, BXO18, BXO19, and BXO20 obtained in 1994 had a different haplotype when compared with the strains collected 
in 1995 (BXOs 443, 444, 445, 446, and 447), which had the BXO1 haplotype.

The two strains from Raipur (BXO2 and BXO3) had distinct haplotypes (Fig. 2A). These haplotypes were, nevertheless, closely related to each other and to the BXO1 haplotype (Fig. 3A). The total number of bands was the same in each of these three strains. The haplotypes of BXO2 and BXO3 differed from that of BXO1 by the absence of one band (albeit a different band in each strain) and the presence of another. As the avrXa10 gene probe detects differences in the number of copies of a 102-bp repeat element within individual members of the avirulence gene family of $X$. oryzae pv. oryzae (9), the haplotypes of $\mathrm{BXO} 2$ and $\mathrm{BXO} 3$ could have arisen by deletion of several copies of this repeat element from a member of the avirulence gene family in BXO1. The possible effect of this change on the virulence of these strains is being investigated. Strains BXO1, BXO2, and BXO3 were found to have identical haplotypes when analyzed with another repeat element probe (discussed below), confirming that they are indeed very closely related.

RFLP analysis with the IS1112 probe. The second probe used was IS1112, a repeat element cloned from the $X$. oryzae pv. oryzae genome (14). A sample of the different haplotypes obtained using this probe is shown in Figure 4A. Eleven distinct haplotypes (seven of them are shown in Fig. 4A) were observed among the strains examined. Band resolution was observed from 8 to $1 \mathrm{~kb}$, therefore, comparisons of bands were made using the 30 bands within this size range. A number of strains from different locations that had identical haplotypes when probed with avrXa10 were also found to have very related haplotypes when probed with IS 1112 (Fig. 4B).

Similarity coefficients were obtained and a dendrogram was prepared (Fig. 3B). One lineage contained 60 strains from 16 different locations and included all the strains that formed a dominant lineage when avrXa10 was used as the probe. Strains within this group clustered together at the $93 \%$ similarity level, and the bootstrap value was $99.9 \%$, indicating that it is a very strong cluster. The BXO38 strain was part of this cluster (haplotype identical to that of BXO33). The bootstrap values for the internal branches within the dominant lineage were $<53 \%$, which suggests that, although the dominant lineage is a very strong cluster, the interrelationships among the strains within this lineage are unclear. Another cluster was formed by BXO5, BXO17, BXO6, and BXO8, with a bootstrap value of $81 \%$; within this cluster, BXO5 and BXO17 (similarity level of $84 \%$ ) were more closely related to each other.

Construction of dendrogram by combining RFLP data obtained with the two probes. The RFLP data obtained by using the probes avrXa10 and IS 1112 were combined and a dendrogram was prepared (Fig. 3C). A dominant lineage comprising 60 strains (including BXO38) from 16 locations was formed at the $93 \%$ similarity level. The bootstrap values were $100 \%$, indicating that this is a very strong cluster. The bootstrap values for the internal branches within the dominant lineage were $<52 \%$, indicating again that, although the dominant lineage is a very strong cluster, the interrelationships between the strains within this lineage are not clear. $\mathrm{BXO} 5, \mathrm{BXO} 17, \mathrm{BXO} 6$, and $\mathrm{BXO} 8$ were related to each other at the $68 \%$ similarity level, but the $64.3 \%$ bootstrap value indicates that this is not a strong cluster. Within this group, strains $\mathrm{BXO5}$ and $\mathrm{BXO} 17$ were more closely related to each other (clustering at the $87 \%$ similarity level), with a bootstrap value of $93 \%$.

Virulence of pathogen strains on differential rice cultivars. The results in Table 2 indicate that the majority (10/14) of the strains tested exhibited a similar virulence spectrum, and these strains belonged to the $\mathrm{BXO} 1$ lineage. $\mathrm{BXO5}, \mathrm{BXO6}, \mathrm{BXO} 8$, and BXO17 were compatible on rice cultivars BJ1 and DV85. The haplotypes of these strains were distinct (Figs. 2 and 4) and quite unrelated (Fig. 3) to those strains that were incompatible with rice
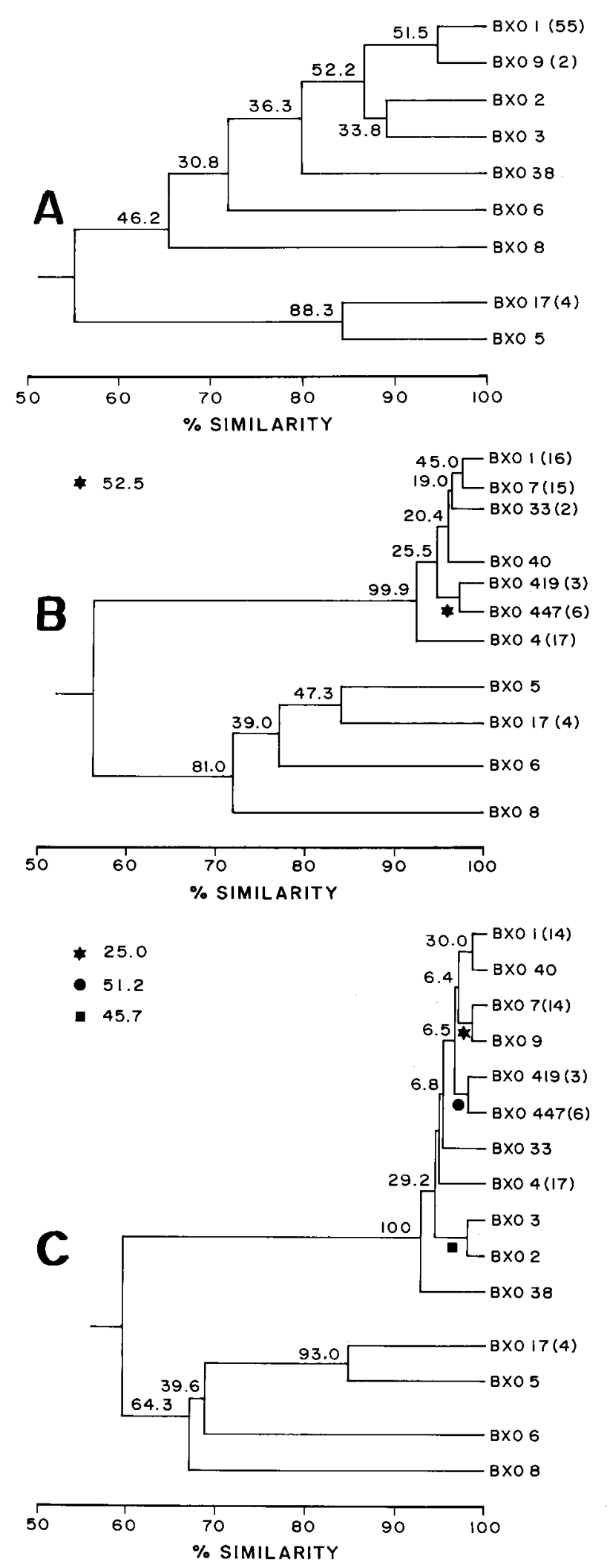

Fig. 3. Dendrograms of Indian strains of Xanthomonas oryzae pv. oryzae derived from restriction fragment length polymorphism (RFLP) studies. The dendrograms were constructed using the UPGMA option of PHYLIP on the basis of RFLP data obtained with A, avrXa10; B, IS1112; and C, the two probes combined. The number of strains that have identical haplotypes are given in parentheses. Numerals or symbols at the internal branches indicate bootstrap values for clusters to the right of the numeral or symbols. Values for the symbols are given in the inset. 

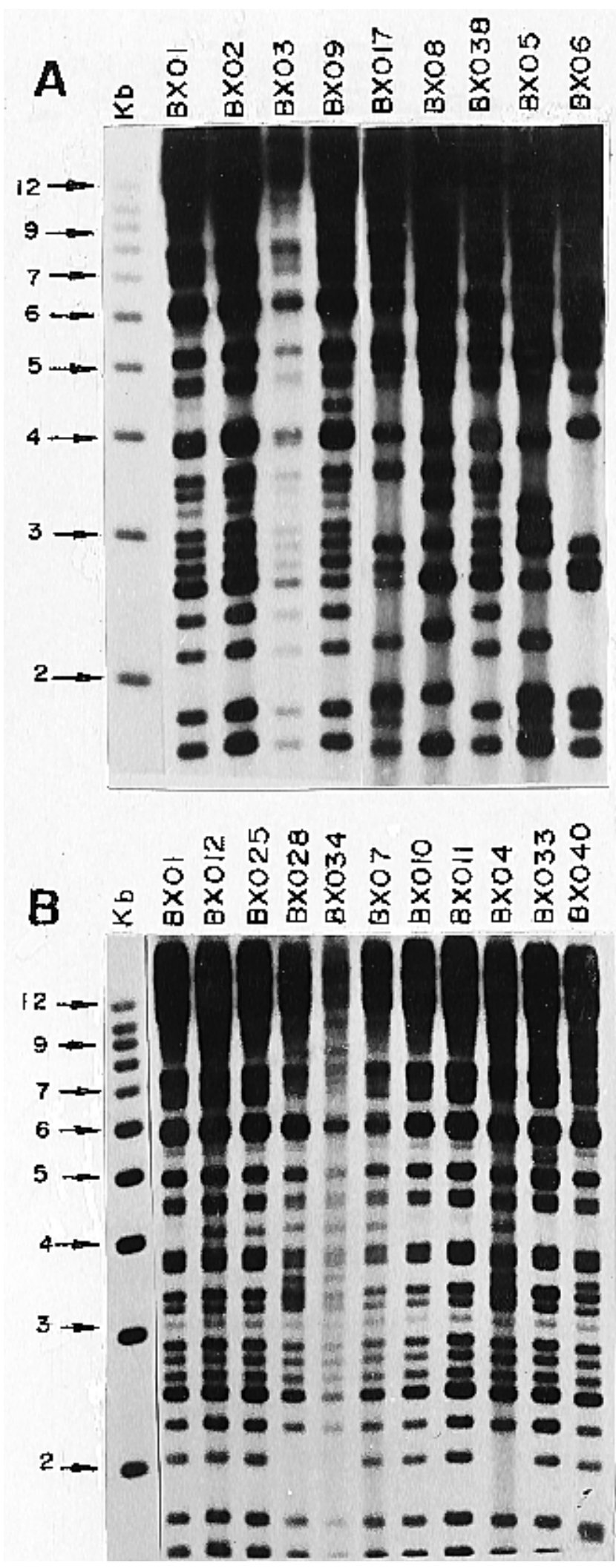

Fig. 4. Haplotype diversity within Indian strains of Xanthomonas oryzae pv. oryzae revealed by the probe IS1112. Genomic DNA was isolated from bacterial strains collected from different locations in India. EcoRI-digested genomic DNA was probed with radio-labeled IS1112. The strain number is indicated on each lane. A kilobase DNA ladder was added as a size marker. Each strain was analyzed at least three times, and the same haplotype was obtained every time. A, Haplotype diversity. B, Haplotypes of a group of closely related strains. cultivars BJ1 and DV85. The strain BXO8 was interesting, as it was compatible with the highly resistant rice cultivar IET8585.

\section{DISCUSSION}

The RFLP studies reported here were initiated to gain a better understanding of the genetic diversity of $X$. oryzae pv. oryzae in India. The results indicate that strains belonging to a single lineage (henceforward referred to as the BXO1 lineage) constitute the majority of this collection of the pathogen. Results obtained with the two probes (combined) indicate that the BXO1 lineage is a very strong cluster (present in $100 \%$ of the clusters obtained by bootstrapping analysis). Although there is diversity within this lineage (the probes used can detect a total of 11 different haplotypes), these strains appear to be closely related to each other, as they cluster together at the $93 \%$ similarity level in the dendrogram. The non-BXO1 lineage strains form a group of loosely related strains, but, among these, BXO5 and BXO17 are most closely related to each other.

The collection sites of the BXO1 lineage strains are, in many cases, separated by several hundred to several thousand kilometers and represent diverse ecological rice-growing areas of the country (Fig. 1). Since multilocus probes were used in this study, it is unlikely that the related haplotypes arose independently at various locations. This suggests that gene flow due to pathogen migration, followed by subsequent divergence in some cases, has occurred. One way that the pathogen could migrate across such large distances is by inadvertent dispersal through seed. We are, therefore, examining the possibility that $X$. oryzae pv. oryzae might be seedborne in India.

The results indicate that all $10 \mathrm{BXO} 1$ lineage strains that were tested are incompatible on rice cultivars BJ1 and DV85. The strains (BXOs 5, 6, 8, and 17) that are compatible on BJ1 and DV85 have haplotypes that are easily distinguishable from the BXO1 lineage. This suggests that, at least at this level, the molecular haplotype might be useful in predicting the pathological properties of Indian strains of $X$. oryzae pv. oryzae. The strains in the BXO1 lineage are compatible on rice cultivar IR20. This suggests that these strains are similar to the previously described pathotype $1 \mathrm{~b}$ of $X$. oryzae pv. oryzae. Pathotype studies conducted during the last 20 years have indicated that pathotype $1 \mathrm{~b}$ is widely distributed in India (18, 19). The results presented here suggest that this continues to be the case.

The rice cultivars $\mathrm{BJ} 1$ and DV85 and their derivatives have been consistently resistant to bacterial leaf blight in the International Rice Bacterial Leaf Blight Nursery, as observed over a number of years (1981 to 1987) and a number of locations in India (18,

TABLE 2. Virulence of Xanthomonas oryzae pv. oryzae strains on differential rice cultivars ${ }^{\mathrm{a}, \mathrm{b}}$

\begin{tabular}{lcccccc}
\hline & \multicolumn{5}{c}{ Rice cultivar } \\
\cline { 2 - 7 } $\begin{array}{l}\text { Bacterial } \\
\text { strain }\end{array}$ & BJ1 & DV85 & $\begin{array}{c}\text { Cempo } \\
\text { Selak }\end{array}$ & IR20 & IET8585 & TN-1 $^{\text {c }}$ \\
\hline BXO1 $^{\text {d,e }}$ & R (3.0) & R (2.5) & S (6.0) & S (6.0) & R (1.0) & S (7.0) \\
BXO6 $^{\text {d,f }}$ & S (5.6) & S (6.0) & S (7.0) & S (6.0) & R (1.0) & S (7.0) \\
BXO8 $^{\text {d }}$ & S (7.0) & S (5.0) & S (6.0) & S (6.0) & S (5.0) & S (7.0) \\
\hline
\end{tabular}

${ }^{a}$ The virulence assays were performed and scored as described in Materials and Methods. $\mathrm{R}=$ resistant and $\mathrm{S}=$ susceptibility. Disease scores are in parentheses.

$\mathrm{b}$ The resistance genes that have been reported (17) to be in these rice cultivars are BJ1 (xa-5 and $x a-13)$, DV85 (xa-5 and Xa-7), Cempo Selak (Xa-3), and IR20 $(X a-4)$. The resistance genes in IET8585 have not been identified. IET8585 was obtained from the cross IR8/BJ1//IR22/CR98-7216.

${ }^{\mathrm{c}} \mathrm{TN}-1=$ Taichung Native- 1 rice cultivar.

${ }^{\mathrm{d}}$ Experiments were repeated twice.

e Similar reactions were obtained with BXOs 4, 7, 9, 10, 12, 25, 28, 33, and 34.

${ }^{\mathrm{f}}$ Similar reactions were obtained with BXO5 and BXO17. 
22). These two cultivars are being used in developing bacterial leaf blight-resistant cultivars in India. IET8585, a derivative of BJ1, is one such cultivar and exhibits resistance to most of the strains used in this study. The resistance genes $x a-5$ and $x a-13$ are present in BJ1, while $x a-5$ and $X a-7$ are found in DV85 (17). Besides these genes, it has been suggested that other major and minor genes for disease resistance may be present in these two cultivars. It remains to be determined which gene(s) in these cultivars are providing resistance against strains within the $\mathrm{BXO1}$ lineage.

\section{ADDENDUM}

Note added in proof. In addition to the results described above, we have analyzed an additional 19 strains that were collected in 1996 from seven different locations in India. Four of these locations had not been sampled earlier; two of the new locations are in the western state of Gujarat. None of the sites sampled earlier were located in this state. All 19 strains belonged to the BXO1 lineage. Their haplotype was identical to that of $\mathrm{BXO} 1$ when avrXa10 was used as a probe and exhibited $>95 \%$ similarity to the BXO1 haplotype when IS1112 was used as a probe.

\section{ACKNOWLEDGMENTS}

This work was supported by a grant to R. V. Sonti from the Department of Biotechnology, Government of India. We thank J. E. Leach for providing the probes used in this study; I. Yap and R. J. Nelson for providing the WinBoot and WinDist software programs; C. B. Rao for help in phylogeny analysis; and K. V. Rao, V. V. Shenoi, P. Balakrishna, N. P. Sharma, and J. Gowrishankar for review of the manuscript.

\section{LITERATURE CITED}

1. Adhikari, T. B., Vera Cruz, C. M., Zhang, Q., Nelson, R. J., Skinner, D. Z., Mew, T. W., and Leach, J. E. 1995. Genetic diversity of Xanthomonas oryzae pv. oryzae in Asia. Appl. Environ. Microbiol. 61:966-971.

2. Bhapkar, D. G., Kulkarni, N. B., and Chavan, V. M. 1960. Bacterial blight of paddy. Poona Agric. Coll. Mag. 51:36-46.

3. Buddenhagen, I. W., and Reddy, A. P. K. 1972. The host, the environment, Xanthomonas oryzae, and the researcher. Pages 289-295 in: Rice Breeding. International Rice Research Institute, Los Banõs, the Philippines.

4. Denny, T. P., Gilmour, M. N., and Selander, R. K. 1988. Genetic diversity and relationships of two pathovars of Pseudomonas syringae. J. Gen. Microbiol. 134:1949-1960.

5. Devadath, S., and Padmanabhan, S. Y. 1969. A preliminary study on the variability of Xanthomonas oryzae on some rice varieties. Plant Dis. Rep. 53:145-148.

6. Felsenstein, J. 1985. Confidence limits on phylogenies: An approach using the bootstrap. Evolution 39:783-791.

7. Felsenstein, J. 1989. PHYLIP-Phylogeny inference package, version 3.41. Cladistics 5:164-166.

8. Hayward, A. C. 1960. A method for characterizing Pseudomonas solanacearum. Nature 186:405-406.

9. Hopkins, C. M., White, F. F., Choi, S.-H., Guo, A., and Leach, J. E. 1992. Identification of a family of avirulence genes from Xanthomonas oryzae pv. oryzae. Mol. Plant-Microbe Interact. 5:451-459.
10. International Rice Research Institute (IRRI). 1980. Page 44 in: Standard Evaluation System for Rice. International Rice Research Institute, Manila, the Philippines.

11. Kauffman, H. E., and Pantulu, R. S. K. V. S. 1972. Virulence patterns and phage sensitivity of Indian isolates of Xanthomonas oryzae. Ann. Phytopathol. Soc. Jpn. 38:68-74.

12. Kauffman, H. E., Reddy, A. P. K., Hsieh, S. P. Y., and Merca, S. D. 1973. An improved technique for evaluating resistance of rice varieties to Xanthomonas oryzae. Plant Dis. Rep. 57:537-541.

13. Leach, J. E., Rhoads, M. L., Vera Cruz, C. M., White, F. W., and Mew, T. W. 1992. Assessment of genetic diversity and population structure of Xanthomonas oryzae pv. oryzae with a repetitive DNA element. Appl. Environ. Microbiol. 54:2188-2195.

14. Leach, J. E., White, F. W., Rhoads, M. L., and Leung, H. 1990. A repetitive DNA sequence differentiates Xanthomonas campestris pv. oryzae from other pathovars of $X$. campestris. Mol. Plant-Microbe Interact. 3: 238-246.

15. Nei, M., and Li, W. 1979. Mathematical model for studying genetic variation in terms of restriction endonucleases. Proc. Natl. Acad. Sci. U.S.A. 76:5269-5273.

16. Nelson, R. J., Baraoidan, M. R., Vera Cruz, C. M., Yap, I. V., Leach, J. E., Mew, T. W., and Leung, H. 1994. Relationship between phylogeny and pathotype for the bacterial blight pathogen of rice. Appl. Environ. Microbiol. 60:3275-3283.

17. Ogawa, T., and Khush, G. S. 1989. Major genes for resistance to bacterial blight in rice. Pages 177-192 in: Proc. Int. Workshop Bacterial Blight Rice. International Rice Research Institute, Manila, the Philippines.

18. Reddy, A. P. K., Srinivasan, T. E., and John, V. T. 1980. Breeding for bacterial leaf blight resistance in rice. Pages 5-13 in: Proc. Natl. Sem. Dis. Resist. Crop Plants. Tamil Nadu Agricultural University, Coimbatore, India.

19. Reddy, M. T. S., and Reddy, A. P. K. 1989. A new pathotype of Xanthomonas campestris pv. oryzae. Int. Rice Res. Newsl. 14:17-18.

20. Reddy, O. R., and Ou, S. H. 1976. Pathogenic variability in Xanthomonas oryzae. Phytopathology 66:906-909.

21. Sambrook, J., Fritsch, E. F., and Maniates, T. 1989. Molecular Cloning: A Laboratory Manual. 2nd ed. Cold Spring Harbor Laboratory Press, Cold Spring Harbor, NY.

22. Seshu, D. V. 1989. Salient findings from the multilocation evaluation of the International Rice Bacterial Blight Nursery. Pages 167-176 in: Proc. Int. Workshop Bacterial Blight Rice. International Rice Research Institute, Manila, the Philippines.

23. Srinivasan, M. C., Thirumalachar, M. J., and Patel, M. K. 1959. Bacterial blight disease of rice. Curr. Sci. 28:469-470.

24. Srivastava, D. N. 1967. Epidemiology and control of bacterial blight of rice in India. Pages 11-18 in: Proc. Symp. Rice Dis. Their Control Growing Resist. Varieties Other Measures. Agriculture, Forestry and Fisheries Research Council, Tokyo.

25. Swings, J., Mooter, M. V., Vauterin, L., Hoste, B., Gillis, M., Mew, T. W., and Kersters, K. 1990. Reclassification of the causal agents of bacterial blight of rice (Xanthomonas campestris pv. oryzae) and bacterial leaf streak (Xanthomonas campestris pv. oryzicola) of rice as pathovars of Xanthomonas oryzae (ex Ishiyama 1992) sp. nov., nom. rev. Int. J. Syst. Bacteriol. 40:309-311

26. Tsuchiya, K., Mew, T. W., and Wakimoto, S. 1982. Bacteriological and pathological characteristics of wild types and induced mutants of Xanthomonas campestris pv. oryzae. Phytopathology 72:43-46.

27. Yap, I., and Nelson, R. J. 1996. WinBoot: A program for performing bootstrap analysis of binary data to determine the confidence limits of UPGMA-based dendrograms. IRRI Discussion Papers Series No. 14. International Rice Research Institute, Manila, the Philippines. 